\title{
I worship, so I download? Idol worship, music purchase and piracy by young consumers in Taiwan
}

\begin{abstract}
Purpose - This study examines the effect of parental and peer norms on idol worship as well as the effect of idol worship on the intention to purchase and obtain the idol's music products legally and illegally.

Design/methodology/approach - A stratified, two-stage, cluster sampling procedure was applied to a list of high schools obtained from the Ministry of Education in Taiwan. A return rate of $80 \%$ yielded 723 usable questionnaires, the data from which were analysed by the LISREL structural equation modelling software.

Findings - The results suggest that both social worship and personal worship have a significant and positive impact on the intention to purchase music. However, personal worship has a negative impact on the intention to pirate music while social worship appears to strengthen it.
\end{abstract}

Research limitations/implications - The findings suggest that idol worship is more complex than previously understood. The constructs chosen in this research should be seen only as a snapshot but other variables such as vanity trait, autonomy, romanticism or involvement are not taken into account. Future studies would benefit from inclusion of these variables and a wider geographical scope.

Practical implications - The findings contain many implications to help marketing executives and planners better revise their existing marketing and communication strategies to increase their revenue.

Originality/value - Existing research has tended to examine the impact of idol worship as a whole on the reduction of music piracy, but overlook the 
two-dimensional aspects of idol worship, hence ignoring the fact that many music firms have not properly utilized idol worship to deal with the challenges associated with music piracy. The findings broaden existing understanding about the causes of two different dimensions of idol worship and their different impacts on the intention to music piracy.

Keywords: Social worship, personal worship, music purchase and piracy, parental norms, peer norms

Paper type: Research paper

\section{Introduction}

Rampant music piracy has become the biggest problem confronting the music industry worldwide. According to Elberse (2010), every 1\% increase in illegal downloads can potentially result in $6 \%$ decrease in album sales. The Office of the United States Trade Representative (USTR) reported that 99\% of music downloads in China are illegal (USTR, 2012). Despite significant increase (28\%) in the value of digital music market (US\$5.9 billion) between 2010 and 2013, global recorded music revenues declined by 3.9\% over the same period due to music piracy (IFPI, 2014). In the US market, music sales had dropped 53\%, from US\$14.6 billion to US\$7.0 billion in 2013 (RIAA, 2014). Numerous anti-piracy initiatives by the music industry, such as educating users and diversifying music channels, have failed to stop both illegal music downloads and declining trend of legal music sales (Ramayah et al., 2009; Robertson et al., 2012). A closer examination of the possible effects of idol worship 
by music marketing firms will be useful in minimizing music piracy.

Some popular music idols such as Lady Gaga and Bruno Mars, however, manage to defy these trends and exhibit superior selling power on their music products, particularly among young consumers around the world (Charbonneau and Garland, 2010; Chiou, Cheng, and Huang, 2011; Yue, Cheung, and Wong, 2010). This implies that there are ways to attract young consumers into purchasing legal music products and it appears that drawing in a large number of fans is one effective way to increase legal music sales. Through repeated media exposure, young consumers with a high level of worshipping a music idol would enthusiastically gather merchandise and information related to the idol or might adopt the idol as a role model. This study intends to incorporate this important factor, idol worship, in our model (see Figure 1) to examine its effects on reducing music piracy and on increasing legal music purchase.

Chiou, Cheng, and Huang (2011) suggested that "studies using different methods to operationalize the effects of artist adoration may be helpful for deeper understanding of the factor's impact on music piracy (p.193).” In other words, a better understanding of the antecedents of idol worship and its impact on music purchase and piracy would enable the music industry to implement more effective strategies to reduce piracy. So far very few idol worship studies have been conducted and published in the consumer 
behaviour area and the results were mixed (Chiou, Cheng, and Huang, 2011; Chiou, Huang, and Lee, 2005; Wang et al., 2009). For instance, Chiou, Cheng, and Huang (2011) found that the attitude of music piracy was negatively affected by the perceived prosecution risk and idol worship among the U.S. student sample. This relationship, however, was not evident among the Taiwanese student sample (Chiou, Cheng, and Huang, 2011). Wang et al. (2009) had found that idol worship moderated the relationship between the intention to illegal downloading and the intention to buy legal music, indicating that a lower level of illegal music downloading intention results in a higher legal music purchasing intention for young consumers with high level of idol worship. However, Chiou, Huang, and Lee (2005) did not find that idol worship could affect the attitude and behavioural intention toward illegal downloading. Based on absorption-addiction model (McCutcheon, Lange, and Houran, 2002), two major dimensions of attitudes and behaviours associated with one’s idol worship were examined in this study - social dimension of idol worship (hereafter referred to as social worship) and personal dimension of idol worship (hereafter referred to as personal worship) (McCutcheon et al., 2006). As mentioned earlier, very few research studies have directly examined the effect of idol worship on music purchase/piracy behaviour. This highlights gaps in existing knowledge on this issue. This study intends to explore how the dimensions of idol worship affect the 
intentions to purchase/pirate music among young consumers.

According to attachment theory (Adams-Price and Greene, 1990), a young adult’s attachment to an idol has been regarded as the secondary attachment that reflects the transition from parental attachment to idol attachment (i.e. the shift away from identification with parents to identification with idol figures). This implies that group norms (e.g. parents and peer) may have significant impact on idol worship since relationships with parents and peers have long been recognized as central elements of the adolescent experience around the world (Brown and Bakken, 2011). However, few research studies have directly examined the effect of group norms on idol worship (Yue, Cheung, and Wong, 2010). Hence, the effect of group norms on idol worship is examined in this study.

The two research objectives of our study are to examine: (1) the effect of parental and peer norms on idol worship; and (2) the effect of idol worship on the intention to purchase and obtain the idol's music products legally and illegally. Recent studies focus on unauthorized/illegal downloading as major form of music piracy (e.g. Bustinza et al., 2013; Chiou, Cheng, and Huang, 2011; Choi and Burnes, 2013; Coyle et al., 2009; Robertson et al., 2012; Wang et al., 2009) since Internet has become an important platform of data exchange. It also facilitates nearly free distribution with little difficulty. Hence, two types of consumer music piracy behaviour are 
differentiated in this study: (1) unauthorized/illegal download; and (2) pirated music product purchasing (Chiou, Huang, and Lee, 2005). In this study, music piracy is defined as the act of illegal music downloading without paying for it (Wang et al., 2009). The remainder of this article is organized as follows. We first define idol worship and provide a brief overview of social worship and personal worship. The factors that influence the idol worship are also explored. We then present a framework delineating whether idol worship mediates between group norms and music purchase and piracy. This is followed by the research methodology and empirical findings. The final section of this paper discusses these findings and their implications for music industry marketers and researchers.

\section{Conceptual Background and Hypotheses Development}

Absorption-addiction model and idol worship

Idol worship, as explained by “absorption-addiction” model of McCutcheon, Lange, and Houran (2002), states that more extreme dimensions of idol worship lead to a compromised identity structure in some individuals. It follows that the psychological absorption with an idol attempts to establish an identity and a sense of fulfilment. This absorption is addictive, which may lead to more extreme (and perhaps delusional) behaviours to sustain the individual's satisfaction with the parasocial relationship, as a 
non-reciprocated but one-directional relationship between fans and idols (Maltby et al., 2006). In essence, McCutcheon, Lange, and Houran (2002) classified three distinct dimensions of idol worship behaviour on a single continuum social, personal, and borderline-pathological (Maltby et al. 2001). At the lowest idol obsession level, social worship, fans have a social level of interest in the idol and this usually encompasses reading and learning about idols (McCutcheon, Lange, and Houran, 2002). The next level up is personal worship in which fans tend to have more intensive and compulsive feelings toward the idol and they usually display this type of behaviour in the company of friends or other fans (McCutcheon, Lange, and Houran, 2002). Fans in the highest level of worship, borderline-pathological, tend to feel that they have a special relationship with the idol and are willing to do anything for the idol (Kowalczyk and Royne, 2013).

The above suggests two major dimensions of attitudes and behaviours associated with one’s idol worship and should be discussed intensively (i.e. social and personal worship). The third dimension and most extreme expression of idol worship, borderline-pathological, reflects an individual's obsessive-addictive attitudes and behaviours, and generally a small number is involved (Hyman and Sierra, 2010; Maltby, Houran, and McCutcheon, 2003; Maltby et al., 2004). Giles and Maltby (2004) found that the idol worship was best explained by a two-factor solution of 
social and personal worship. Hence, borderline-pathological worship is excluded from this study. The two dimensions of social and personal worship can occur simultaneously within an individual (Kowalczyk and Royne, 2013; McCutcheon, Lange, and Houran, 2002). A social worshipper (hereafter referred to as social fan) is defined in this study as someone who holds a significantly higher level of social idol worship than the personal aspect of idol worship. A personal worshipper (hereafter referred to as personal fan) is defined here as an individual who holds a substantially higher level of personal idol worship than the social idol worship.

\section{Group norms and idol worship}

Social norms perspective suggests that reference groups regulate the conduct of their members through the establishment and reinforcement of norms (Fisher and Ackerman, 1998). Fisher and Ackerman (1998, p. 263) have defined group norms as the "perceptions, attitudes, and behaviours that are approved of by the reference group (e.g. parents and peers) and expected of its members”. Group norms specify what group should or ought to do in a particular situation (Cialdini, Kallgren, and Reno, 1991). Group norms are informal rules that are not usually written down or discussed openly but have a strong influence on behaviours of individuals within the reference group (Feldman, 1984). Individuals who comply with group norms are usually 
rewarded for their actions whereas those who do not may receive punishments or outright rejection (Festinger, Schachter, and Back, 1950; Li et al., 2009). Reference groups' approval for idol worship of young consumers may increase referents' support and praise towards their attachment relationship with idols. Such support will be regarded as norms rewards toward idol worship. Young consumers who receive reference groups' approval are likely to have idol attachment relationships characterized by higher levels of trust and satisfaction (Collins and Read, 1990; Hazan and Shaver, 1987; Kirkpatrick and Davis, 1994; Shaver and Brennan, 1992).

As mentioned earlier, parents and peers are two central elements of the adolescent experience and development (Brown and Bakken, 2011). Therefore, parental and peer norms have been examined in this study as the most important referent group norms in adolescence. Attachment theory suggests that the ideal attachment figure provides physical proximity and a secure base from which one can explore the world (Arseth et al., 2009; Bowlby, 1958). For example, the children may perceive parents as a safe haven from which to explore and check for the availability of the attachment figures. When threat arises the children may seek protection from the parents who serves as a safe haven (Mayseless and Popper, 2007). Limited literature has concurrently focused on the influence of both parental and peer norms. For example, Giles and Maltby (2004) argued that idol attachment can increase emotional autonomy by reflecting the 
transition from parental attachment to peer attachment. After controlling for age-related effects, they found that high emotional autonomy was a significant predictor of idol worship and that idol worship was significantly related to low attachment to parents and high attachment to peers. Chester et al. (2007) had found that parental norms can reduce and even eliminate negative influences of peer norms, even among families who have single-parent status. This may partially explained by the absorption-addiction model, which indicates that the deficit in the adolescent's identity plays as a determinant of idolising (Maltby et al., 2004). The findings of Maltby et al. (2004) argued that young consumer's deficits in various aspects, such as attachment to parents and parental norms, were positively related to idol worship. This is because the parental norms which facilitate adolescents' identity development would discourage young consumers from idol worship. Cheung and Yue (2012) also provided evidence that the absence in the adolescent's parental resources would prompt the young consumer to idolise star idols. These findings suggest that young consumers are likely to keep themselves away from idol worship because they find in their parental relationships that provide confidence and resource that support their identity development. This implies that parental norms may have a negative effect on idol worship. Hence, the following hypothesis is derived:

$\mathbf{H}_{\mathbf{1}}$ Parental norms have a significant negative effect on (a) social worship; and (b) 
personal worship.

As discussed earlier, parental and peer norms can impact on young consumer's idol worship differently. During adolescence, attachment figures are usually directed toward persons outside the family. An idol or peer may serve as a principal attachment figure for young consumers. Some researchers suggested that parents are not relinquished as attachment figures but that other people (e.g. idols) are gradually added as attachment figures and, in many cases, these new figures come to replace parents' position at the top of an attachment hierarchy (Allen and Land, 1999; Hazan and Zeifman, 1994). This happens as young consumers become more autonomous and individuated and as they realize that their parents are not as strong and all-knowing as they had once thought (Weiss, 1991). Raviv et al. (1996) found that peer groups had played an important role in influencing adolescents who were in a transitional stage from family system to society. Having a more marginal status in adult society, adolescents tend to look for the guidance and support from their peers as well as to conform to their values, attitudes and patterns of behaviour. The research by Raviv et al. (1996) also found that peer influence was positively associated with idol worship by adolescents. Chan and Prendergast (2008) found peer norms had strong positive effects on creation of high desires for approaching idols' standards of living. On the 
basis of the existing findings, this implies that peer norms have a positive effect on idol worship. Hence, the following hypothesis is derived:

$\mathbf{H}_{2}$ Peer norms have a significant positive effect on (a) social worship; and (b) personal worship.

Social worship and music piracy

This first dimension of attitudes and behaviours associated with idol worship is social worship (Maltby et al., 2006). Social worship represents a lower level of idol worship (Maltby et al., 2006). This dimension of idol worship is characterized by moderate behaviours (e.g. watching, reading and learning about the idols) purely for purposes of social entertainment (McCutcheon et al., 2003). The attraction to their favourite idols is manifested through the perceived ability to entertain and the possession of a social focus (Maltby et al., 2006). Social worship reflects the social aspects of idol worship and is consistent with Stever's (1991) observation that fans are attracted to an idol because of that idol's ability to capture attention and entertain.

Results from studies utilizing the Celebrity Attitude Scale (Maltby et al., 2004, 2006; McCutcheon et al., 2002) suggest that social worship has entertainment-social value and comprise the attitudinal and behavioural questions such as "My friends and I like to discuss what my favourite idol has done" and "Learning the life story of my 
favourite idol is a lot of fun". The results are consistent with findings from other studies that that idol worship can be an important means for self-concept maintenance (Chiou, Cheng, and Huang, 2011; Chiou, Huang, and Lee, 2005) and identity development (Giles and Maltby, 2004). Young consumers are attracted to idols because they want to acquire the idealised self-identity for self-enhancement (Swann et al., 1992). According to attachment theory, this is likely to result in consumers possessing a negative view of self-concept (i.e. low self-congruity), which in turn generating a fear of abandonment by loved idols and then leading them to attempt to associate themselves with the idols (Swaminathan, Stilley, and Ahluwalia, 2009). Therefore, social worship is viewed as an important determinant affecting young consumers' intention to purchase their idol's legal music products since the possession of idol's related merchandises is a way to attach with their idols (Chiou, Cheng, and Huang, 2011; Chiou, Huang, and Lee, 2005). Thus, $\mathbf{H}_{3 \mathbf{a}}$ Social worship has a significant positive effect on the intention to purchase legal music products.

Given that idol has been treated as a human brand (Thomson, 2006) and that social worship usually involves with hedonic behaviours and activities such as listening idol's albums, sharing idol's events with friends, and seeking information to keep up 
with idol, fans may regard idol brand as a provider of the hedonic value (Holbrook and Hirschman, 1982). The hedonic value is defined as a subjective and experiential assessment and results more from fun and playfulness than from task completion (Holbrook and Hirschman, 1982). According to the theory of consumption values (Sheth et al., 1991), consumers make purchase decisions after considering multiple value dimensions such as enjoyment and their hedonic value. In other words, consumers follow their own cognitive decision processes and reflect on multiple value dimensions before they make a decision to purchase or download illegal music products. Specifically, the hedonic music value reflects music fans' potential entertainment and emotional worth (Babin, Darden, and Griffin, 1994). An on-line music environment has the potential to generate much of hedonic values since the free music download websites are prevalent on the Internet. Hence, the extent to which the activity and process of using the computer is perceived to be enjoyable in its own right (Davis, Bagozzi, and Warshaw, 1992) and is a determinant of the consumers enjoyment of online music. Babin, Darden, and Griffin (1994) found that behaviours such as "hedonic shopping value” played a special part in compulsive owning of goods in an online environment. Thus, we argue that the hedonic experience by fans can enhance the enjoyment and novelty of on-line music piracy.

The attitude of fans toward the hedonic value is another element to be considered. 
Yoo and Lee (2009) found that fans, in the process of pursuing hedonic values, would easily accept music piracy without worrying about the music quality or feeling embarrassed. Not surprisingly, they found that the attitudes toward the hedonic value of pirated goods purchase had a significant positive impact on the purchase intention of pirated goods (Yoo and Lee, 2009). Chaudry and Stumpf (2011) also found that consumers' willingness to purchase pirated goods stems from a hedonic on-line shopping experience. Thus, young consumers who display higher level of social worship may obtain their idol's music products either legally or illegally because of their perceived ability to entertain and to become a source of social interaction and gossip. Hence, we propose the following hypotheses:

$\mathbf{H}_{3 \mathbf{b}}$ Social worship has a significant positive effect on the intention to download illegal music products.

Personal worship and music purchase

The second dimension, personal worship, represents a more extreme dimension of idol worship and leads to a compromised identity structure. The feelings for the idol, in comparison with social worship, are more compulsive and intensive, and their behaviours go beyond that of a moderate nature, whereby fans share their obsessional tendencies with a larger audience of other fans or friends (Giles, 2000; McCutcheon, 
Lange, and Houran, 2002; McCutcheon et al., 2003).

The absorption-addiction model reveals that personal worship has a stronger attachment to idol than social worship (Hyman and Sierra, 2010; McCutcheon, Lange, and Houran, 2002). The attachment nature of personal worship is also compatible with the self-expansion model's concept of inclusion of other in the self (Aron et al., 2005). Self-expansion theory (Aron et al., 2005) states that individuals have an inherent motivation for self-expansion, or a desire to include the other in the self. By including an entity or an idol in the self, an individual may increase the bond that connects them. As the bonds between self and idol grow closer, the line between self and idol gets blurred and harder to differentiate, leading to enhanced self-idol overlap and relationship satisfaction. Some studies argued that the strength of idol attachment depends on the degree to which fans personally see the idol as being part of themselves, reflecting who they are (e.g. Malär et al., 2011; Park et al., 2010). Idols that usually have higher social status and talents are more likely to be included in the fans' self. In other words, the more the idol reflects the fans' self and the stronger the personal bond the fans perceive between the self and the idol, the greater the idol attachment becomes. Several studies provided evidence that brand attachment played an important role in consumers' actual purchase intention and behaviours (Park et al., 2010; Swaminathan, Stilley, and Ahluwalia, 2009). 
Maltby et al. (2004) found that personal worship was negatively related to the cognitive flexibility. This may imply that fans with high personal worship could be associated with low level of cognitive flexibility and they would be less likely than other people in possessing the mental capacity to adjust thinking or attention in response to changing goals or environmental stimuli (Cheung and Yue, 2012; Martin and Anderson, 2001). In other words, they lack the mental ability to adjust their thinking from old situations to new situations and therefore, would be very reluctant to overcome previously held beliefs or habits (Martin and Anderson, 2001; Martin, Anderson, and Thweatt, 1998). Simply put, young consumers with high personal worship are likely to be loyal to specific idols and therefore are likely to purchase music products of their favourite idols. Thus, the following hypothesis is derived:

$\mathbf{H}_{4 \mathbf{a}}$ Personal worship has a significant positive effect on the intention to purchase legal music products.

As music piracy is illegal, it is a matter of moral judgment which affects consumers' own ethical decision process to determine whether to pirate or not. The issue-contingent model proposes that the moral intensity of the issue such as piracy has a significant impact on consumer's ethical decision process (Jones, 1991). The higher the intensity of a moral issue, the more people will identify it, and thus the less 
likely that one will approve of or engage in unauthorized piracy (Seiler, Fischer and Voegtli, 2011). The model also proposes that moral intensity is consisted of six components: magnitude of consequences, social consensus, probability of effect, temporal immediacy, proximity, and concentration of effect (Jones, 1991). In particular, the proximity dimension, defined as a feeling of psychological nearness that the moral agent has toward the victim of the unethical act (Jones, 1991), is highly related to the topic of this study. Attachment theory indicates that individuals have obvious relevance to closeness processes in adolescence since they need to maintain security through the regulation of physical proximity and psychological closeness to attachment idols. Based on self-expansion theory, for most fans idols have been included in the self, and thus become an important part of self. Therefore, the feeling of psychological nearness that the fans have for the idols should be very strong for the objects of this study. This leads to fans caring more about idols who are psychologically close to them than they do for people who are distant. The moral intensity on illegal downloading is likely to increase if it is related to music products of their favourite idols. Therefore, the intention to pirate music is likely to reduce. Simply put, young consumers with high personal worship are likely to be loyal to specific idols and therefore are likely to be reluctant to download and obtain illegal download music products of their favourite idols. Thus, the following hypothesis is 
derived:

$\mathbf{H}_{\mathbf{4 b}}$ Personal worship has a significant negative effect on the intention to download illegal music products.

The four hypotheses above mainly focus on examining the relationship between young consumer's idol worship and their behavioural intentions to obtain music products legally or illegally. In order to ensure that the constructs in relation to behavioural intentions to purchase and pirate music behave as they should in relation to other constructs within the model, we need to assess the nomological validity (Pennings and Smidts, 2000). Nomological validity refers to whether measures are related to other constructs in a way that is theoretically meaningful (Pennings and Smidts, 2000). To do this, we adapted procedures set out by Klein et al. (1998) and Pennings and Smidts (2000) to examine the relationships between the intentions to purchase and pirate music and the actual behaviour in purchasing and pirating music. Therefore, we included in the model measures of actual frequency counts of the number of music products respondents purchased legally and downloaded illegally of their favourite idols. Thus, the following hypotheses are derived:

$\mathbf{H}_{5 \mathbf{a}}$ The intention to purchase legal music products has a significant positive effect on the frequency counts of the number of music products purchased. 
$\mathbf{H}_{\mathbf{5 b}}$ The intention to obtain illegal music products has a significant positive effect on the frequency counts of the number of music products downloaded illegally.

\section{Methodology}

Research model

Figure 1 depicts the eight associated research constructs and the causal paths to the frequency counts of the number of music products purchased and obtained legally and illegally from parental and peer norms and social and personal worship, via the intention to purchase and obtain music products legally and illegally. The individual causal links are expressed in the five pairs of research hypotheses to be tested by structural equation modelling of data collected by a survey on young consumers in Taiwan. In addition, novelty seeking is included in Figure 1 as a control variable and no new hypothesis has been developed to investigate its direct effect on other variables. We believe that young consumers' novelty seeking trait would affect their intention to illegally download and purchase music. Manning et al. (1995) indicate that novelty seeking behavior is a global personality trait, which represents consumer's tendency to search for new information and is most closely associated with the initial stage of the product adoption process. Novelty seeking may arise out of consumers' satiation with the music they frequently listen to, particularly for music 
products with low search costs and risks. Consumers are then looking for appropriate information about the products and attempt to get satisfaction from the experience (Dobre et al., 2009; Wee et al., 1995).

\section{------Insert Figure 1 here-----}

\section{Sample selection}

As the first step in recruitment of the eventual respondents, a stratified, two-stage, cluster sampling procedure was applied to a list of high schools obtained from the Ministry of Education in Taiwan. The participants consisted of students selected from two types of school: senior high (approximately 15-18-years-old) and vocational high schools (approximately 15-18-years-old). On the basis of cluster analysis using the population density and the educational levels of each district involved, all schools were stratified into metropolitan area and suburban or township area. In the first stage, a total of 9 schools were selected using a probability proportional to size (PPS) method from each type of school within each stratum: 4 of 196 senior high and 1 of 76 vocational high schools for the metropolitan area, and 3 of 144 senior high and 1 of 79 vocational high schools for the suburban or township area. In the second stage, one class from each grade (three grades in each type of schools) within the sampled schools was randomly selected. All students of the selected classes were eligible for 
this study. Data were collected between March 2012 and June 2012. The purpose of our study was explained to the principals and teachers. Parents were informed of the survey by letter and asked to notify the researchers if they did not want their child to participate. Our study was explained to the students by the researchers or teachers about two weeks in advance and again by researchers on the survey day. Students were given the choice of participation. Because the students' answers were anonymous, parental permission was not sought. Before the test, all students of each class went to a classroom together, where the procedures were explained by trained survey staff members. Students were asked to complete the questionnaire in the classroom after written informed consent was obtained.

Of the 900 enlisted students, 810 (90\%) students participated in the study. Questionnaires with missing data on the important questions (e.g. music purchase intention) were excluded from the subsequent analyses (87 returned with missing items ranging from 2 to 13 for each individual). The final sample was 723, which resulted in an overall response rate of $80 \%$.

Chi-squared goodness-of-fit tests, on the four age groups as shown in Table 1, showed that the sample respondents were not significantly different to the target population (population statistics published by National Statistics Taiwan (http://www.stat.gov.tw)) $(\chi 2=5.47, \mathrm{df}=3, p>0.05)$. The research sample is thus 
acceptably representative of the target population. As a further check against non-response bias, late returns were compared with earlier responses, following Armstrong and Overton (1977). There were no significant differences between the two sub-samples for disposable income level $(p=0.672)$. Table 1 provides a profile of the sample. The majority of the respondents were between 15 and 18 years old (66\% of the respondents were between 16-17 years of age). The male/female split was close to 50/50. The majority of the students (35\%) were Grade 11 and personal monthly disposable income is under US\$ 31.3 (40\%).

\section{------Insert Table 1 here-----}

\section{Questionnaire design}

The questions to elicit the data for modelling the constructs contained in Hypotheses 1 to 5 were adapted from Fishbein and Ajzen (1975), Fisher and Ackerman (1998), McCutcheon, Lange, and Houran (2002), Robertson et al. (2012), Swee et al. (2001), and Wee, Tan, and Cheok (1995). A pilot test of the questionnaire was carried out by surveying 50 young consumers, and a series of preliminary semi-structured face-to-face interviews was also conducted with young consumers in Taiwan. Results from pilot test strongly suggested that the eventual respondents would be reluctant to spend the necessary time on the questionnaire if the questions remained as numerous. 
The number was therefore reduced, in order to increase willingness to participate in the study as well as to reduce respondent fatigue or response biases (Hinkin, 1995). The pilot test also found that only a small number of fans would fall into the borderline-pathological worship dimension and hence this dimension was excluded from this study. This is consistent with findings by Giles and Maltby (2004) in which they found that the idol worship was best explained by a two-factor solution of social and personal worship. The pilot interviews furthermore explored respondents' understanding and beliefs of every question, their opinions about the questions asked, and any issues raised by the range of questions asked or the response options offered. Valuable feedback was received and the questionnaire duly modified before the survey started.

To ensure accurate rendition of the original English questions in Chinese, one bilingual colleague translated them and a second rendered them back into English. This back-translation procedure follows the methodological lead of Bhalla and Lin (1987) and follows the guidelines in a standard textbook of international market research (Douglas and Craig, 1983). The process resulted in modifications to ensure comprehensibility among the eventual respondents.

The eventual questionnaire directed respondents to express their agreement or disagreement with statements relating to the eight main constructs and other variables 
(including the control variable), excluding frequency of music purchase and piracy, in Figure 1 on Likert scales anchored at $1=$ strongly disagree and $7=$ strongly agree The sequence of the questions followed that in a research study of consumer's intention to purchase goods by Klein (2002), to reduce possible bias in respondents' responses if questions about a specific idol came earlier in the questionnaire. Respondents were randomly assigned questionnaires. Questionnaires differed in order and combinations of two groupings measuring: (a) parental norms, peer norms, social worship, and personal worship; and (b) intentional to purchase music and intentional to pirate music. Demographical and other questions succeeded each questionnaire. Two conditions were formed (letters correspond to order of item groupings $\mathrm{x}$ to $\mathrm{y}$ in a given questionnaire): (1) xy and (2) yx. We then applied a series of T tests between the two conditions and no significant difference was found in the sample $(p=0.17 \sim 0.64)$.

The measures relating to parental norms and peer norms were adapted from the work of Fishbein and Ajzen's (1975) and Fisher and Ackerman's (1998), in which a three-item scale measured young consumer's belief about the feeling and reaction of parents and peer group in performing certain action, respectively. The measures of social worship were adapted from a study by McCutcheon, Lange, and Houran (2002), which used a seven-item scale to produce a composite measure of social set of idol 
worship. Since the loading for one of the items loading is less than 0.70 , the original scale was subsequently reduced to six items to measure respondent's tendency to worship their favourite idol. The items relating to personal worship was adapted from a ten-item measure in a study by McCutcheon, Lange, and Houran (2002), but reduced to four statements in response to the low factor loadings for some of the items as well as to the outcome of the pilot study and semi-structured preliminary interviews with Taiwanese young consumers. The factor loading for each of the remaining four items is higher than 0.85 .

With regard to the selection of the single most favourite idol (SMFI), the study followed the procedures used by Thomson (2006). Initially, respondents were asked to list a number of their favourite singers, including solo artists and bands, with a series of idol cues for reminders. Then, they were asked to indicate their SMFI from the above list.

Two four-item scales were adapted from studies by Swee et al. (2001) and Wee, Tan, and Cheok (1995) to measure the respondents' intention to purchase music as well as the intention to pirate music. Both the music purchase frequency and music piracy frequency constructs consist of an one-item scale which was adapted from Robertson et al. (2012). The music purchase frequency scale measured the average number of legal music albums or songs released by the respondents' SMFI they had purchased 
per month while the music piracy frequency scale measured measure the average number of music albums or songs released by the respondents' single most favourite idol they had downloaded illegally per month. The respondents were presented with the following response categories (on a seven-point scale): (1) 0 album/0 mp3 songs purchased per month, (2) 1 album/10 or fewer songs purchased per month, (3) 2 albums/10-19 songs purchased/pirated per month, (4) 3 albums/30-39 songs purchased/pirated per month, (5) 4 albums/40-49 songs purchased/pirated per month, (6) 5 albums/50-59 songs purchased/pirated per month, (7) more than 6 albums/more than 60 songs purchased/pirated per month. Theses two seven-point scales were used as the single indicator of the frequency counts of the number of music products purchased/pirated, with the error variance set equal to the smallest estimated error variance $\left(\Theta_{\varepsilon}\right)$ in the model (Anderson and Gerbing, 1988; Klein, Ettenson, and Morris, 1998).

------Insert Table 2 here-----

\section{Data Analysis and Results}

Reliability and validity

Reliability analysis was conducted on the eight constructs to be measured: parental norms, peer norms, social worship, personal worship, intention to purchase legal music products, intention to download illegal music products, music purchase 
frequency, and music piracy frequency. In every case, the Cronbach's alpha coefficient was greater than 0.88 , indicating acceptable internal consistency (Nunnally, 1978). Table 3 presents the reliability and validity statistics for all constructs.

------Insert Table 3 here-----

The data were analysed by structural equation modelling. Although stronger correlations were found only among some independent variables, it has been argued by Seo (2005) and Kline (2006) that this technique can be used to measure any intercorrelations among predictors so long as no multicollinearity is present. Therefore, four regression models were constructed, in which the intention to, and the frequency counts of the number of music products purchased legally as well as downloaded illegally were the dependent variables. The maximum variance inflation factor in all cases was less than 1.462, and the average was less than 1.292, indicating that multicollinearity was not unduly influencing the least squares estimates (Neter, Wasserman, and Kutner, 1985).

With preliminary checks for potential correlation and multicollinearity problems completed, the data were tested for reliability and validity by LISREL 8.72 (Jöreskog and Sörbom, 1993). Confirmatory factor analysis assessed the correspondence of all items with their respective latent variables. Every construct in the measurement model 
was treated as a separate reflective measure. The resulting indices were chi-square $\left(\chi^{2}\right)=471.884$ (252 degrees of freedom (d.f.)) and $p=0.000$. The conclusion is that the model fits the data well.

Given the use of self-reporting in the questionnaire answers for this study, common method bias could have been a threat to validity. However, steps were taken in this study to mitigate any potential effects of method bias. First, four measurement models were conducted, performing the Harman's single factor test by using a confirmatory approach (e.g. Iverson and Maguire 2000; McFarlin and Sweeney, 1992; Shoham et al., 2006). The first pair of models followed the constructed model; the second pair allowed all items to load on a single factor. The latter monomethod analysis resulted in chi-square values of 815.422 (d.f. $=329, \chi^{2}$ /d.f. $\left.=2.48\right)$. The relative fit indices were: $p$-value $=0.000, \mathrm{NFI}=0.965, \mathrm{CFI}=0.979, \mathrm{GFI}=0.928$, and RMSEA $=0.045$. Compared with the second model, the one following the constructed model exhibited lower chi-square values of 471.884 (d.f. $=252, \chi^{2} /$ d.f. $=1.87$ ). The first model also had superior fit indices: $\mathrm{NFI}=0.979, \mathrm{CFI}=0.990, \mathrm{GFI}=0.952$ and $\mathrm{RMSEA}=0.035$. Second, the Harman's single factor test was performed using an exploratory factor analysis (e.g. Podsakoff and Organ, 1986) to ensure that no one general factor emerged and accounted for the majority of covariance between the independent and dependent variables. The results showed that no single factor accounted for the majority of the 
variance. All eight un-rotated variables loaded on different factors with the first factor accounted for less than $40 \%$ of total variance, suggesting that common method variance was not of great concern and was not likely to pose a significant threat to the findings of this study.

Convergent validity was confirmed in every case by the ranges of all factor loadings and the measurement errors, which were both acceptable and significant at alpha $=0.05$. Content validity had already been established by pilot-testing the questionnaire in interviews with potential respondents and academic and practitioner experts, to control against inconsistency between the measurement items and the precedents in the literature reviewed. Following the recommendation of Churchill (1979), convergent and discriminant validities were also tested for the four antecedent constructs. The former was assessed by examining the composite reliability of the measures, which ranged from 0.87 to 0.91 against a recommended minimum value of 0.70 (Hair et al., 2006). Discriminant validity was assessed by measuring the AVE statistic (Fornell and Larcker, 1981), which varied between 0.55 and 0.78, higher in every case than the largest squared pairwise correlation of 0.19 between each construct (Espinoza, 1999). To sum up, the items and scales exhibited acceptable levels of reliability and validity, as confirmed by the summary statistics shown in Table 3. 
Hypotheses testing

Table 4 presents the results of structural equation modelling of both the independent and dependent constructs. The statistics they display $-\chi 2$, CFI, NFI and RMSEA offer convincing evidence that the overall fit of the proposed model is satisfactory.

\section{------Insert Table 4 here-----}

The estimates, standard errors and t-values shown in the rows 1 and 2 in Table 4 indicate that the level of parental norms is not positively related to both social worship and personal worship ( $\beta=0.05$ and $0.08, p>0.05)$. Respondents could not relate the approval and support from parents to their own social and personal idol worship. The findings provide no support for $\mathrm{H}_{1 \mathrm{a}}$ and $\mathrm{H}_{1 \mathrm{~b}}$ (see Figure 2).

\section{------Insert Figure 2 here-----}

The statistics in the rows 3 and 4 demonstrate a significant and positive relationship between the peer norms and the degrees of the respondents' social and personal worship $(\beta=0.43$ and $0.33, p<0.05)$. Both $\mathrm{H}_{2 \mathrm{a}}$ and $\mathrm{H}_{2 \mathrm{~b}}$ are thus supported, in that the belief that getting approval and support from their peers play a crucial and dominant part in the generation of idol worship. 
Support for $\mathrm{H}_{3 a}$ and $\mathrm{H}_{3 \mathrm{~b}}$ is offered by the estimates, standard errors and t-values in the rows 5 and 6, which demonstrate a significant and positive relationship between the degree of respondents' social worship and their intentions to purchase/pirate music $(\beta=0.46$ and $0.12, p<0.05)$.

In the rows 7 and 8 , the statistics confirm the prediction that this dimension of idol worship is related to the level of the intentions to purchase/pirate music among Taiwanese young consumers. The degree of respondents' personal worship has a positive impact on their intention to purchase music whereas personal worship is negatively related to the intention to pirate music $(\beta=0.10$ and $-0.32, p<0.05)$. These findings support $\mathrm{H}_{4 a}$ and $\mathrm{H}_{4 b}$. The statistics in the row 9 and 10 support $\mathrm{H}_{5 \mathrm{a}}$ and $\mathrm{H}_{5 \mathrm{~b}}$ in showing that respondents' intentions to purchase/pirate music have a significant and positive effect on the frequency counts of the number of music products purchased as well as downloaded illegally $(\beta=0.37$ and $0.33, p<0.05)$. The intentions to purchase/pirate music were found to be particularly strong predictors of the behaviour to music purchase and piracy. In addition, the sole control variable of this study, novelty seeking, is not positively related to the intention to purchase music $(\beta=0.02$, $p>0.05$ ) but is significantly and positively related to the intention to pirate music $(\beta=0.31, p<0.05)$. This suggests that respondents who desire to search for new information on music artists would strengthen their intention to download illegal 
music products.

\section{Test of mediating effects}

Next, we examined the mediating role of idol worship. The mediation test was conducted while controlling for the influences of all other variables in the model. This approach has been adopted in many SEM studies (Holmbeck, 1997; Maxham and Netemeyer, 2002). Following existing practice (Baron and Kenny, 1986), the effect of mediation is confirmed, when (1) the independent variable (i.e. parental norms and peer norms) affects the mediating variable (i.e. social worship and personal worship), (2) the mediating variable influences the dependent variable (i.e. intention to purchase and piracy), (3) the mediating variable is related to the dependent variable, and (4) the effect of the independent variable on the dependent variable is lower (or non-significant) when the mediating variable is included in the model. The complete mediation occurs when the mediating variable is included and no effect between independent and dependent variables has been detected. When the effect between independent and dependent variables decreases by a nontrivial amount, but not to zero, partial mediation is demonstrated. Inconsistent mediation model occurs when the direct and mediated effects of an independent variable on an dependent variable have opposite signs (see Items 7 and 8 in Table 5) (MacKinnon, Fairchild and Fritz, 2007). 
According to MacKinnon, Fairchild and Fritz (2007), this could be the case that the independent variable does not affect the mediating variable, but there is still mediation.

Overall, the model fits the data well, and all lambdas are large and significant ( $p$ $<.05$ ), for example NFI and CFI are larger than 0.90. All the mediation conditions are met, apart from wherein social worship acts as mediating variable between norms and intention to music piracy (see Items 5 and 6 in Table 5). This could be explained by the fact that perceived parental and peer norms do not significantly influence intention to music piracy whether or not social worship is included in the model. We further verify such mediating effect through the use of the Sobel test, which examines whether norms exert an indirect effect on intention to purchase or pirate music through idol worship. The Sobel test produces a test statistic (Z), along with accompanying significance levels. We used Preacher and Leonardelli's (2006) interactive mediation tool to conduct the Sobel test. Similar to the previous results, we have found that the indirect effect from norms to intention to purchase music through idol worship is statistically significant $(\mathrm{Z}=3.61 \sim 7.01, p<0.05)$ whereas personal worship has a mediating effect on the relationship between the norms and the intention to pirate music $(\mathrm{Z}=-4.30$ and $-5.34, p<0.05)$. This confirms that at least one component of the idol worship dimensions, namely the "personal worship", has a 
mediating effect on the relationship between the norms and the intentions to purchase and pirate music. Thus, the mediating role of idol worship should not be neglected.

\section{Discussion and Conclusion}

Our study has examined the antecedents of idol worship and its impact on the intentions and behaviour of Taiwanese young consumers toward music purchase and piracy, thus answering the call for deeper understanding of idol worship's impact on music piracy (Chiou, Cheng, and Huang, 2011), and solving the puzzle of mixed results among relations between idol worship and music piracy. The testing of five specific hypotheses confirms most of the expectations, and provides several insights into the applicability of the idol worship on music product purchasing behaviour.

First, absorption-addiction model, attachment theory, and self-expansion theory together can be used to explain the findings that both social worship and personal worship had a significant and positive impact on the intention to purchase music. This is consistent with anecdotal evidence found in the literature (Wang et al., 2009). However, social worship and personal worship were found to impact on the intention to pirate music differently. This may explain why major record labels have invested a lot of time and efforts in creating and promoting idols in the popular music and yet have largely failed to stop music piracy. Prior studies have focused on a specific 
dimension of social worship as a proxy for the idol worship, and found mixed results. For example, Chiou, Huang, and Lee (2005) employed the social worship as the measure of idol worship and found no significant relationship between idol worship and the intention to pirate music. Therefore, our findings contribute by providing possible explanations for these mixed results in previous studies (e.g. Chiou, Cheng, and Huang, 2011; Chiou, Huang, and Lee, 2005; Wang et al., 2009). The two dimensions of idol worship may constitute the ultimate determinants of the intentions to purchase/pirate music. While the importance of idol worship has been recognized in the marketing literature, empirical work on these two dimensions of idol worship (social worship and personal worship) and their impacts on the intentions to purchase/pirate music are limited. We propose that to assess idol worship one needs to look beyond the specific dimension and include the other dimension of idol worship, personal worship.

Second, very few studies have been conducted on the opposite effects of social worship and personal worship on the intention to pirate music. Our results are not consistent with previous studies. For example, both Chiou, Huang, and Lee (2005) and Chiou, Cheng, and Huang (2011) found that social worship was not related to the intention to pirate music among Taiwanese students. However, our findings suggest that the theory of consumption values can be used to explain the findings that social 
worship had a significant and positive impact on the intention to pirate music. Social fans were often associated with social and hedonic traits and believed that enjoyment could be derived when browsing, listening, and downloading to online music and may also be motivated by sharing with friends. As pointed out by Chiou, Huang, and Lee (2005), Taiwanese students believe that music files sharing might promote the publicity of the idols as well as share their feeling and view of the idol's music. This might lead them to regard both music piracy and purchase as some form of entertainment and social interaction. However, marketers often overlooked consumer activities that involve leisure and play (Holbrook and Hirschman, 1982). Music firms should make every effort to convince the fans that it is both fun and cool to purchase legitimate music products as one source of resisting music piracy.

Third, personal fans were generally associated with higher level of idol attachment which may partly be motivated by expanding idols into their self-expansion process. Such finding confirms that attachment theory and self-expansion theory together can be used to explain that personal worship has a significant and negative impact on the intention to pirate music. This is consistent with findings by Chiou, Cheng, and Huang's (2011) who found that personal worship had a significant and negative impact on intention to pirate music among U. S. students. This appears to imply that personal fans (with high idol attachment) would be reluctant to pirate music while 
social fans (with low idol attachment) would be more likely to download music of their favourite idols illegally.

Finally, young consumers who were susceptible to peer norms were more likely to exhibit worship towards a favourite idol, suggesting that peer norms played the pivotal part in creating "idol worship", and that it is therefore important to identify the “peer referents” who can exert significant influence on young consumers. In addition, while past literature has suggested that group norms increase idol worship (Wang et al., 2009), our results suggest that personal worship mediates the impact of group norms on the intention to purchase/pirate music. Our work corroborates with that of Cheng (1997) who found, in his case study of a fan-club member, personal worship was associated with strong fear of negative evaluation by others. Furthermore, these results are also partially consistent with previous work in which peer norms were examined as an antecedent to desires for approaching idols’ standards of living (Chan and Prendergast, 2008). From a marketing view point, the findings emphasize the role of peer norms in influencing young consumers and its role in enabling personal worship and, consequently, the intention to purchase/pirate music.

\section{Managerial implications}

Our findings have several implications for marketing management practice. First, they 
show that the existence of "social worship" and "personal worship", as defined in the literature, had a positive and significant influence on respondents' intention to purchase legal music products, confirming the previous general assumption. Therefore, we put forward the recommendations to assist in encouraging young consumers to purchase legal music products. Results in our study suggest that young consumers will purchase their favourite idols’ music products not only because of enjoying idols’ voice and talents, but also because of their intensive attachment with the idols. Marketing strategists would be well advised, therefore, to identify market segments containing probable high-worship young consumers, and to target them with a communication strategy that may generate the image of the musical singers from that of their talents to strengthen young consumer's social focus, and emphasize distinctive features (e.g. excitement and ruggedness) that enable attraction to young consumer's personal focus (Aaker, 1997; Lin and Lin, 2007). Music firms should be careful in formulating appropriate marketing strategies (e.g. special offers and incentives, more intimate interactions between fans and idols via mailing list, emails or social media) to target both social and personal fans.

Second, a closer examination of the idol worship constructs has revealed that personal worship has a negative impact on the intention to pirate music while social worship has a positive influence on the intention to pirate music. Music marketing 
firms should take note of the fact that different strategies are required for reducing illegal downloads and for increasing legal music purchase. Too much focus on idols' social and hedonic aspects may encourage piracy of their music products. Instead, these firms need to take more proactive steps to motivate and inform both social and personal fans what the idol wants them to do: "be close to me", "thinking about me often”, and "letting me be part of you”. For example, a good strategy to target social fans would be to maintain their attention and interests in the idol by providing them with access to sample audio and video from time to time. As for the personal fans, the emphasis would be to provide them with idol's stories and gossips in order to make it personal and let them feel close to a "rock star". Developing the idea among personal fans that piracy not only breaches the law but also harms the idols themselves might discourage music piracy because they intend to include idols in the self as an entity.

Third, music firms can assist in providing an attractive platform for both idols and their fans to interact in order to increase the young consumers' fascination in and desire to be close to their idols, resulting in increased level of personal worship. With the growth in social networks such as Facebook, Twitter, and Tumblr, idols are able to increase their fan base. Social networks will allow idols to monitor and respond to the opinions of their fans in a timely manner, particularly with their music products. Idols can also get in touch with those young consumers who may not have reached the 
higher level of personal worship by emphasizing their lifestyles and talents which can attract social fans and transfer them into personal fans. Popular American artist Lady Gaga is a perfect example of an idol who is influencing her fans at all levels of the idol worship dimensions. She has been using her Facebook website as an interactive platform to share, on a daily basis, private pictures, music videos, and personal status messages with her fans. In 2010, she gratefully acknowledged in her Facebook website the fans who camped outside of the Today Show venue the day before she appeared on the show. By using social networks, marketing firms may help idols to influence consumers at the different dimensions of idol worship, particularly in connecting to personal fans and in reducing music piracy.

Fourth, our study has found that peer norms have a positive impact on idol worship. From the marketing firms' perspective, building a good brand image of the idol through advertising and promotion strategies, such as being a spokesperson for a brand or product that is congruent with the image of the idol or serving as a role model, could profitably assist in persuading and motivating peer referents to accept their idols (e.g. Justin Timberlake or Lady Gaga). Through the participation of the online communities (i.e. Facebook, Twitter, and Tumblr) or other promotional events, this type of young consumers are likely to form a sense of identity from being a member of the idol fan group. 
Finally, the intention to purchase music has a positive effect on music purchase frequency. This shows that music firms can increase the revenue of their music products if they can keep up with shifting consumer behaviour by stimulating young consumers' intention to purchase their favourite music. The proposed antecedents of this study will provide stronger marketing intelligence about the constructs that actually contribute to the practical development of the intentions to purchase/pirate music.

\section{Limitations and future directions}

The findings suggest that idol worship is more complex than previously believed. The related constructs included in this research, though pointing the way forward in development of a coherent conceptual framework, should be seen only as a snapshot.

Our review of the literature made it clear that other variables such as vanity trait, autonomy, romanticism or involvement may need to be taken into account (Malär et al., 2011; Thomson, 2006). For instance, Yue and Cheung (2000) asserted that "romanticism" is an important predictor for the selection of favourite idols. These character traits would be expected to influence their consumption decisions, and future research models should therefore build in such variables.

Our study has not established unequivocally that parental norms and peer norms are 
indeed antecedents of idol worship, as distinct from simply correlates. For example, it is possible that owning plenty of music products of an idol might reinforce worship towards idol, as some other authors have pointed out. Our model has tacitly assumed antecedent relationships, and demonstrated the links fairly convincingly, but more research is needed to establish that these constructs actually result in idol worship, which might use an experimental design to investigate likely causal direction. Moreover, more confirmatory studies are necessary to further examine and validate the social and personal worship scales used in this study. For example, the scale of brand attachment used by Park et al. (2010) and the attachment strength scale of human brand employed by Thomson (2006) may be considered as alternative measurements. Furthermore, since our study focuses mainly on young consumers (below 19 years old), there is a need to gain wider demographic by targeting mature population for future research. Finally, the application of group norms scale is limited to Taiwan, a country strongly influenced by Confucianism. Whether the concept is applicable to other cultural settings (e.g. Western culture), which hold weak force of group conformity, is unknown at this time. It is possible that in other countries friends in-group identity may result in decreased idol worship. These issues should be explored in future studies. 


\section{References}

Aaker, J.L. (1997), “Dimensions of brand personality”, Journal of Marketing Research, Vol. 34 No. 3, pp. 347-56.

Adams-Price, C. and Greene, A.L. (1990), "Secondary attachments and adolescent self-concept”, Sex Roles, Vol. 22 No. 3/4, pp. 187-98

Allen, J.P. and Land, D. (1999), “Attachment in adolescence”, in Cassidy, J. and Shaver, P.R. (Eds.), Handbook of Attachment: Theory, Research, and Clinical Applications, Guilford Press, New York, pp. 319-35

Anderson, J.C. and Gerbing, D.W. (1988), “Structural equation modeling in practice: a review and recommended two-step approach”, Psychological Bulletin, Vol. 103, pp. 411-23.

Armstrong, J.S. and Overton, T. (1977), "Estimating non-response bias in mail survey”, Journal of Marketing Research, Vol. 14 No. 3, pp. 396-402.

Aron, A., Fisher, H., Mashek, D.J., Strong, G., Li, H. and Brown, L.L. (2005), "Reward, motivation, and emotion systems associated with early-stage intense romantic love”, Journal of Neurophysiology, Vol. 94, pp. 327-37.

Arseth, A.K., Kroger, J., Martinussen, M. and Marcia, J.E. (2009), "Meta-analytic studies of identity status and the relational issues of attachment and intimacy", Identity: An International Journal of Theory and Research, Vol. 9, pp. 1-32. 
Babin, B., Darden, W. and Griffin, M. (1994), "Work and/or fun: measuring hedonic and utilitarian shopping value”, Journal of Consumer Research, Vol. 20, pp. 644-56.

Bhalla, G. and Lin, L. (1987), "Cross cultural marketing research: a discussion of equivalence issues and management strategies”, Psychology \& Marketing, Vol. 4 No. 4, pp. 275-85.

Bowlby, J. (1958), “The nature of the child’s tie to his mother”, International Journal of Psychoanalysis, Vol. 39, pp. 350-73.

Brown, B.B. and Bakken, J.P. (2011), "Parenting and peer relationships: reinvigorating research on family-peer linkages in adolescence”, Journal of Research on Adolescence, Vol. 21 No.1, pp.153-65.

Bustinza, O. F., Vendrell-Herrero, F., Parry, G. and Myrthianos, V. (2013), "Music business models and piracy”, Industrial Management \& Data Systems, Vol. 113, No. 1, pp. 4-22.

Chan, K. and Prendergast, G.P. (2008), “Social comparison, imitation of celebrity models and materialism among Chinese youth”, International Journal of Advertising, Vol. 27, No. 5, pp. 799-826.

Charbonneau, J. and Garland, R. (2010), "Product effects on endorser image the potential for reverse image transfer”, Asia Pacific Journal of Marketing and 
Logistics, Vol. 22 No. 1, pp. 101-10.

Chaudry, P.E. and Stumpf, S.A. (2011), “Consumer complicity with counterfeit products”, Journal of Consumer Marketing, Vol. 28, pp. 139-51.

Cheng, S.T. (1997), "Psychological determinants of idolatry in adolescents", Adolescence, Vol. 32 No. 127, pp. 687-92.

Chester, C., Jones, D.J., Zalot, A. and Sterrett, E. (2007), “The psychosocial adjustment of African American youth from single mother homes: the relative contribution of parents and peers”, Journal of Clinical Child and Adolescent Psychology, Vol. 36 No. 3, pp. 356-66.

Cheung, C. K. and Yue, X. D. (2012), “Idol worship as compensation for parental absence”, International Journal of Adolescence and Youth, Vol. 17 No. 1, pp. $35-46$.

Chiou , J.S., Cheng, H.I. and Huang, C.Y. (2011), “The effects of artist adoration and perceived risk of getting caught on attitude and intention to pirate music in the United States and Taiwan”, Ethics and Behavior, Vol. 21 No. 3, pp. 182-96.

Chiou, J.S., Huang, C.Y. and Lee, H.H. (2005), “The antecedents of music piracy attitudes and intentions”, Journal of Business Ethics, Vol. 57, pp. 161-74.

Choi, H., and Burnes, B. (2013), "The internet and value co-creation: the case of the popular music industry", Prometheus, Vol. 31, No. 1, pp. 35-53. 
Churchill, G.A. (1979), “A paradigm for developing better measures of marketing constructs”, Journal of Marketing Research, Vol. 16, pp. 64-73.

Cialdini, R.B., Kallgren, C.A. and Reno, R.R. (1991), “A focus theory of normative conduct: a theoretical refinement and reevaluation of the role of norms in human behavior”, in Berkowitz, L. (Ed.), Advances in Experimental Social Psychology, Vol. 24, Academic Press, New York, pp. 201-14.

Collins, N. and Read, S.J. (1990), “Adult attachment, working models, and relationship quality in dating couples”, Journal of Personality and Social Psychology, Vol. 58 No. 4, pp. 644-63.

Coyle, J.R., Gould, S.J., Gupta, P. and Gupta, R. (2009), “To buy or to pirate: the matrix of music consumers' acquisition-mode decision-making”, Journal of Business Research, Vol. 62, pp. 1031-37.

Davis, F., Bagozzi, R. and Warshaw, P. (1992), "Extrinsic and intrinsic motivation to use computers in the workplace”, Journal of Applied Social Psychology, Vol. 22, pp. 1111-32.

Dobre, C., Dragomir, A. and Preda, G. (2009), “Consumer innovativeness: a marketing approach”, Management and Marketing, Vol. 4 No. 2, pp. 19-34.

Douglas, S.P. and Craig, C.S. (1983), International Marketing Research, Prentice-Hall, Englewood Cliffs, NJ. 
Elberse, A. (2010), "Bye-bye bundles: the unbundling of music in digital channels”, Journal of Marketing, Vol. 74, pp. 107-23.

Espinoza, M.M. (1999), “Assessing the cross-cultural applicability of a service quality measure: a comparative study between Quebec and Peru”, International Journal of Service Industry Management, Vol. 10, pp. 449-68.

Feldman, D.C. (1984), “The development and enforcement of group norms”, Academy of Management Review, Vol. 9, pp. 47-53.

Festinger, L., Schachter, S. and Back, K. (1950), Social Pressures in Informal Groups, Harper, New York.

Fishbein, M. and Ajzen, I. (1975), Belief Attitude, Intention, and Behavior: An Introduction to Theory and Research, Addison-Wesley, Reading, MA.

Fisher, R.J. and Ackerman, D. (1998), “The effects of recognition and group need on volunteerism: a social norm perspective”, Journal of Consumer Research, Vol. 25 No. 3, pp. 262-75.

Fornell, C. and Larcker, D.F. (1981), "Evaluating structural equation models with unobservable variables and measurement error”, Journal of Marketing Research, Vol. 18, pp. 39-50.

Giles, D.C. (2000), Illusions of Immortality: A Psychology of Fame and Celebrity, MacMillan, London. 
Giles, D.C. and Maltby, J. (2004), “The role of media in adolescent development: relations between autonomy, attachment and interest in celebrities”, Personality and Individual Differences, Vol. 36, pp. 813-22.

Giles, D. and Maltby, J. (2006), “Praying at the altar of the stars”, Psychologist, Vol. 19 No. 2, pp. 82-5.

Hair, J.F., Black, W.C., Babin, B.J., Anderson, R.E. and Tatham, R.L. (2006), Multivariate Data Analysis, Pearson Education, Upper Saddle River, NJ.

Hazan, C. and Shaver, P.R. (1987), “Romantic love conceptualized as an attachment process”, Journal of Personality and Social Psychology, Vol. 52 No. 3, pp. 511-24.

Hazan, C. and Zeifman, D. (1994), "Sex and the psychological tether”, in Bartholomew, K. and Perlman, D. (Eds.), Attachment Processes in Adulthood. Advances in Personal Relationships, Vol. 5, Jessica Kingsley, London, pp. 151-78.

Hinkin, T.R. (1995), “A review of scale development practises in the study of organisations”, Journal of Management, Vol. 21, No. 5, pp. 967-88.

Holbrook, M. and Hirschman, E. (1982), “The experiential aspects of consumption: consumer fantasies, feelings, and fun”, Journal of Consumer Research, Vol. 9, pp. $132-40$. 
Holmbeck, G.N. (1997), “Toward terminological, conceptual, and statistical clarity in the study of mediators and moderators: examples from the child-clinical and pediatric psychology literature”, Journal of Consulting and Clinical Psychology Vol. 65 No. 4, pp. 599-610.

Hyman, M.R. and Sierra, J.J. (2010), “Idolizing sport celebrities: a gateway to psychopathology?”, Young Consumers: Insight and Ideas for Responsible Marketers, Vol. 11, pp. 226-38.

IFPI, International Federation of the Phonographic Industry (2014), “IFPI digital music report: lighting up new markets”, available at: http://www.ifpi.org/ downloads/Digital-Music-Report-2014.pdf.pdf (accessed 1 August 2014).

Iverson, R.D. and Maguire, C. (2000), “The relationship between job and life satisfaction: evidence from a remote mining community”, Human Relations, Vol. 53 No. 4, pp. 807-39.

Jones, T.M. (1991), “Ethical decision making by individuals in organizations: an issue-contingent model”, Academy of Management Review, Vol. 16 No. 2, pp. 366-95.

Jöreskog, K.G. and Sörbom, D. (1993), LISREL 8: Structural Equation Modeling with the SIMPLIS Command Language, Scientific Software International, Chicago.

Kirkpatrick, L.A. and Davis, K.E. (1994), “Attachment style, gender, and relationship 
stability: a longitudinal analysis”, Journal of Personality and Social Psychology, Vol. 66 No. 3, pp. 502-12.

Klein, J.G. (2002), “Us versus them, or us versus everyone? delineating consumer aversion to foreign goods”, Journal of International Business Studies, Vol. 33 No. 2, pp. 345-63.

Klein, J.G., Ettenson, R. and Morris, M.D. (1998), “The animosity model of foreign product purchase: an empirical test in the People's Republic of China”, Journal of Marketing, Vol. 62 No. 1, pp. 89-100.

Kline, R.B. (2006), Principles and Practice of Structural Equation Modeling, Guilford, New York.

Kowalczyk, C.M. and Royne, M.B. (2013), “The moderating role of celebrity worship on attitudes toward celebrity brand extensions", Journal of Marketing Theory and Practice, Vol. 21 No. 2, pp. 211-20.

Li, J., Mizerski, D., Lee, A. and Liu, F. (2009), “The relationship between attitude and behavior: an empirical study in China”, Asia Pacific Journal of Marketing and Logistics, Vol. 21 No. 2, pp. 232-42.

Lin Y.C. and Lin, C.H. (2007), "Impetus for worship: an exploratory study of adolescents' idol adoration behaviors”, Adolescence, Vol. 42 No. 167, pp. $575-88$. 
MacKinnon, D.P., Fairchild, A.J. and Fritz, M.S. (2007), "Mediation analysis", Annual Review of Psychology, Vol. 58, pp.593-614.

Malär, L., Krohmer, H., Hoyer, W.D. and Nyffenegger, B. (2011), “Emotional brand attachment and brand personality: the relative importance of the actual and the ideal self”, Journal of Marketing, Vol. 75, pp. 35-52.

Maltby, J., Day, L., McCutcheon, L.E., Houran, J. and Ashe, D. (2006), "Extreme celebrity worship, fantasy proneness and dissociation: developing the measurement and understanding of celebrity worship within a clinical personality context”, Personality and Individual Differences, Vol. 40, pp. 273-83.

Maltby, J., Day, L., McCutcheon, L.E., Martin, M.M. and Cayanus, J.L. (2004), “Celebrity worship, cognitive flexibility, and social complexity”, Personality and Individual Differences, Vol. 37, pp. 1475-82.

Maltby, J., Houran, J. and McCutcheon, L.E. (2003), “A clinical interpretation of attitudes and behaviors associated with celebrity worship”, Journal of Nervous and Mental Disease, Vol. 191 No. 1, pp. 25-9.

Manning, K.C., Bearden, W.O. and Madden, T.J. (1995), “Consumer innovativeness and the adoption process”, Journal of Consumer Psychology, Vol. 4 No. 4, pp. 329-45. 
Martin, M.M. and Anderson, C.M. (2001), “The relationship between cognitive flexibility and affinity-seeking strategies”, Advances in Psychological Research, Vol. 4, pp. 69-76.

Martin, M.M., Anderson, C.M. and Thweatt, K.S. (1998), “Individuals’ perceptions of their communication behaviors: a validity study of the relationship between the Cognitive Flexibility Scale and the Communication Flexibility Scale with aggressive communication traits”, Journal of Social Behavior and Personality, Vol. 13, pp. 531-40.

Maxham, J.G. and Netemeyer R.G. (2002), "Modeling customer perceptions of complaint handling over time: the effects of perceived justice on satisfaction and Intent”, Journal of Retailing, Vol. 78 No. 4, pp. 239-52.

Mayseless, O. and Popper, M. (2007), "Reliance on leaders and social institutions: an attachment perspective”, Attachment and Human Development, Vol. 9 No. 1, pp. 73-93.

McCutcheon, L.E., Ashe, D.D., Houran, J. and Maltby, J. (2003), “A cognitive profile of individuals who tend to worship celebrities”, Journal of Psychology, Vol. 137 No. 4, pp. 309-22.

McCutcheon, L.E., Lange, R. and Houran, J. (2002), “Conceptualization and measurement of celebrity worship”, British Journal of Psychology, Vol. 93, pp. 
67-87.

McCutcheon, L.E., Scott, V.B. Jr., Aruguete, M.S. and Parker, J. (2006), “Exploring the link between attachment and the inclination to obsess about or stalk celebrities”, North American Journal of Psychology, Vol. 8 No. 2, pp. 289-300.

McFarlin, D.B. and Sweeney, P.D. (1992), “Distributive and procedural justice as predictors of satisfaction with personal and organizational outcomes”, Academy Management Journal, Vol. 35 No. 3, pp. 626-37.

Neter, J., Wasserman, W. and Kutner, M.H. (1985), Applied Linear Statistical Models, Richard D. Irwin, Homewood, IL.

Nunnally, J.C. (1978), Psychometric Theory, McGraw-Hill, New York.

Park, C.W., MacInnis, D.J., Priester, J., Eisingerich, A.B. and Iacobucci, D. (2010), "Brand attachment and brand attitude strength: conceptual and empirical differentiation of two critical brand equity drivers”, Journal of Marketing, Vol. 74, pp. 1-17.

Pather, S. and Uys, C.S. (2008), "Using scale reduction techniques for improved quality of survey information: peer reviewed article”, South African Journal of Information Management, Vol. 10, No. 3, pp. 1-7.

Pennings, J. M. E., and Smidts, A. (2000), “Assessing the construct validity of risk attitude”, Management Science, Vol. 46 No. 10, pp.1337-48. 
Podsakoff, P.M. and Organ, D.W. (1986), “Self-reports in organizational research: problem and process”, Journal of Management, Vol. 12 No. 4, pp. 531-44.

Preacher K.J. and Leonardelli G.J. (2006), “Calculation for the Sobel test: an interactive calculation tool for mediation tests”, available at: http://quantpsy.org/sobel/sobel.htm (accessed 10 August 2014).

Ramayah, T., Ahmad, N.H., Chin, L.G. and Lo, M.-C. (2009), "Testing a casual model of internet piracy behavior among university students”, European Journal of Scientific Research, Vol. 29 No. 2, pp. 206-14.

Raubenheimer, J. (2004), “An item selection procedure to maximise scale reliability and validity”, South African Journal of Industrial Psychology, Vol. 30, No. 4, pp. 59-64.

Raviv, A., Bar-Tal, D., Raviv, A. and Ben-Horin, A. (1996), “Adolescent idolization of pop singers: causes, expressions, and reliance”, Journal of Youth and Adolescence, Vol. 25 No. 5, pp. 631-50.

RIAA, The Recording Industry Association of America (2014), "Piracy: scope of the problem”, available at: http://www.riaa.com/physicalpiracy.php?content_ selector =piracy-online-scope-of-the-problem (accessed 27 September 2014).

Robertson, K., McNeill, L., Green, J. and Roberts, C. (2012), “Illegal downloading, ethical concern, and illegal behavior”, Journal of Business Ethics, Vol. 108 No. 
2, pp. 215-27.

Seiler, S., Fischer, A. and Voegtli, S.A. (2011), “Developing moral decision-making competence: a quasi-experimental intervention study in the Swiss armed forces”, Ethics and Behavior, Vol. 21 No. 6, pp. 452-70.

Seo, D.-C. (2005), “An explicative model of unsafe work behavior”, Safety Science, Vol. 43 No. 3, pp. 187-211.

Shaver, P.R. and Brennan, K.A. (1992), “Attachment styles and the 'big five' personality traits: their connections with each other and with romantic relationship outcomes”, Personality and Social Psychology Bulletin, Vol. 18 No. 5, pp. 536-45.

Sheth, J.N., Newman, B.I. and Gross, B.L. (1991), "Why we buy what we buy-a theory of consumption values”, Journal of Business Research, Vol. 22 No. 2, pp. 159-70.

Shoham, A., Davidow, M., Klein, J.G. and Ruvio, A. (2006), “Animosity on the home front: the Intifada in Israel and its impact on consumer behavior”, Journal of International Marketing, Vol. 14 No. 3, pp. 92-114.

Stever, G.S. (1991), “The celebrity appeal questionnaire”, Psychological Reports, Vol. 68, pp. 859-66.

Swaminathan, V., Stilley, K.M. and Ahluwalia, R. (2009), “When brand personality 
matters: the moderating role of attachment styles”, Journal of Consumer Research, Vol. 35, pp. 985-1002.

Swann, W.J., Seroussi, A.L. and Giesler, R.B. (1992), "Why people self verify”, Journal of Personality and Social Psychology, Vol. 66 No. 5, pp. 857-69.

Swee, H.A., Cheng, P.S., Lim, A.C. and Tambyah, S.K. (2001), "Spot the difference: consumer responses towards counterfeit”, Journal of Consumer Marketing, Vol. 18 No. 3, pp. 219-35.

Thomson, M. (2006), “Human brands: investigating antecedents to consumers’ strong attachments to celebrities”, Journal of Marketing, Vol. 70 No. 3, pp. 104-19.

Thomson, M., MacInnis, D.J. and Park, C.W. (2005), “The ties that bind: measuring the strength of consumers' emotional attachments to brands”, Journal of Consumer Psychology, Vol. 15 No. 1, pp. 77-91.

USTR, Office of the United States Trade Representative (2012), “2012 special 301 report”, available at: http://www.ustr.gov/sites/default/files/ 2012\%20Special\%20301\%20Report_0.pdf (accessed 1 August 2014).

Wang, C.C., Chen, C.T., Yang, S.C. and Farn, C.K. (2009), "Pirate or buy? the moderating effect of idolatry”, Journal of Business Ethics, Vol. 90 No. 1, pp. 81-93.

Wee, C.H., Tan, S.J. and Cheok, K.H. (1995), “Non-price determinants of intention to 
purchase counterfeit goods: an exploratory study”, International Marketing Review, Vol. 12 No. 6, pp. 19-46.

Weiss, R.S. (1991), “The attachment bond in childhood and adulthood”, in Parkes, C. M., Stevenson-Hinde, J. and Marris, P. (Eds.), Attachment across the Life Cycle, Routledge, New York, pp. 66-76.

Yoo, B. and Lee, S.H. (2009), “Buy genuine luxury fashion products or counterfeits?”, Advances in Consumer Research, Vol. 36, pp. 280-86.

Yue, X.D. and Cheung, C.K. (2000), "Selection of favorite idols and models among Chinese young people: a comparative study in Hong Kong and Nanjing”, International journal of Behavioral Development, Vol. 24 No. 1, pp. 91-8.

Yue, X.D., Cheung, C.-K. and Wong, D.S.W. (2010), “From glamour-oriented idolatry to achievement-oriented idolatry: a framing experiment among adolescents in Hong Kong and Shenzhen”, Asian Journal of Social Psychology, Vol. 13 No. 1, pp. 1-8. 
Table1.

Sample Characteristics

\begin{tabular}{lccccc}
\hline Demographic variables & $\mathrm{N}$ & $\%$ & Demographic variables & $\mathrm{N}$ & $\%$ \\
\hline Age & & \multicolumn{5}{c}{ Regular class } \\
Under 15 & 106 & 15 & Grade 10 & 241 & 33 \\
16 & 252 & 35 & Grade 11 & 251 & 35 \\
17 & 227 & 31 & Grade 12 & 231 & 32 \\
18 and over & 138 & 19 & Personal monthly disposable income in US\$ \\
& & & Under \$ 31.3 & 290 & 40 \\
Gender & & & \$ 31.4-62.6 & 180 & 25 \\
Male & 362 & 50 & \$ 62.7-156.5 & 186 & 26 \\
Female & 361 & 50 & Over \$ 156.6 & 67 & 9 \\
\#Conversion rate for NT\$ to US\$=1:0.03024 in June, 2013 &
\end{tabular}


Table 2.

Measurement items, factor loading and t-value of each item.

\begin{tabular}{|c|c|c|}
\hline Construct/Item & Loadings & t-Values \\
\hline \multicolumn{3}{|l|}{ Parental norms } \\
\hline 1. If you worshiped an idol, your parents will approve of your conduct. & 0.741 & 19.789 \\
\hline 2. If you worshiped an idol, your parents will regard it as wise. & 0.805 & 21.341 \\
\hline 3. If you worshiped an idol, your parents will regard it as alright. & 0.924 & 24.686 \\
\hline \multicolumn{3}{|l|}{ Peer norms } \\
\hline 1. If you worshiped an idol, your best friend will approve of your conduct. & 0.858 & 26.768 \\
\hline 2. If you worshiped an idol, your best friend will regard it as wise. & 0.913 & 29.457 \\
\hline 3. If you worshiped an idol, your best friend will regard it as alright. & 0.876 & 27.209 \\
\hline \multicolumn{3}{|l|}{ Social worship } \\
\hline 1. My friends and I like to discuss what my SMFI ${ }^{\#}$ has done. & 0.708 & 20.529 \\
\hline 2. I enjoy watching, reading, or listening to SMFI because it means a good time. & 0.758 & 21.495 \\
\hline 3. I love to talk with others who admire SMFI. & 0.751 & 22.110 \\
\hline 4. Learning the life story of SMFI is a lot of fun. & 0.764 & 23.342 \\
\hline 5. It is enjoyable just to be with others who like SMFI. & 0.809 & 25.184 \\
\hline $\begin{array}{l}\text { 6. I like watching and hearing about SMFI when I am with a large group of } \\
\text { people. }\end{array}$ & 0.833 & 26.320 \\
\hline \multicolumn{3}{|l|}{ Personal worship } \\
\hline 1. When something bad happens to my SMFI I feel like it happened to me. & 0.864 & 28.591 \\
\hline 2. I have frequent thoughts about my SMFI, even when I don’t want to. & 0.889 & 29.819 \\
\hline 3. When SMFI dies (or died) I will feel (or I felt) like dying too. & 0.881 & 29.298 \\
\hline $\begin{array}{l}\text { 4. When SMFI fails or loses at something I feel like a failure myself. } \\
\text { Intention to purchase music }\end{array}$ & 0.859 & 28.003 \\
\hline 1. I prefer to purchase music products released by my SMFI. & 0.772 & 23.235 \\
\hline 2. I hope others would purchase music products released by SMFI. & 0.843 & 26.001 \\
\hline $\begin{array}{l}\text { 3. I would watch out for where I can purchase music products released by } \\
\text { SMFI. }\end{array}$ & 0.863 & 25.601 \\
\hline $\begin{array}{l}\text { 4. If I know where to purchase music products released by SMFI, I would } \\
\text { inform my relatives and friends. }\end{array}$ & 0.803 & 24.849 \\
\hline \multicolumn{3}{|l|}{ Intention to pirate music } \\
\hline 1. I prefer to download music products related to my SMFI. & 0.821 & 24.936 \\
\hline $\begin{array}{l}\text { 2. I hope others would download music products released by SMFI without } \\
\text { paying for it. }\end{array}$ & 0.754 & 22.917 \\
\hline $\begin{array}{l}\text { 3. I would watch out for where I can download music products released by } \\
\text { SMFI without paying for it. }\end{array}$ & 0.825 & 25.925 \\
\hline $\begin{array}{l}\text { 4. If I know where to download music products released by SMFI without } \\
\text { paying for it, I would inform my relatives and friends. }\end{array}$ & 0.851 & 26.265 \\
\hline \multicolumn{3}{|l|}{ Music purchase frequency } \\
\hline $\begin{array}{l}\text { 1. The average number of legal music albums or songs released by the } \\
\text { respondents' SMFI they had purchased per month. }\end{array}$ & 1.000 & 38.048 \\
\hline \multicolumn{3}{|l|}{ Music piracy frequency } \\
\hline $\begin{array}{l}\text { 1. The average number of music albums or songs released by the respondents' } \\
\text { SMFI they had downloaded illegally per month. }\end{array}$ & 1.000 & 38.000 \\
\hline \multicolumn{3}{|l|}{ Novelty seeking } \\
\hline 1. I often seek out information about new singers and albums. & 0.723 & 21.320 \\
\hline $\begin{array}{l}\text { 2. I like to go to places where I will be exposed to information about new } \\
\text { singers and albums. }\end{array}$ & 0.735 & 22.689 \\
\hline 3. I frequently look for new singers and albums. & 0.769 & 23.821 \\
\hline 4. I like media that introduce new singers and albums. & 0.854 & 25.805 \\
\hline $\begin{array}{l}\text { 5. I seek out situations in which I will be exposed to new and different sources } \\
\text { of singers and albums information. }\end{array}$ & 0.860 & 26.044 \\
\hline 6. I am continually seeking new singers and albums experiences. & 0.837 & 25.087 \\
\hline $\begin{array}{l}\text { 7. When I go shopping, I find myself spending very little time checking out new } \\
\text { singers and albums }{ }^{\ddagger} \text {. }\end{array}$ & 0.848 & 25.524 \\
\hline $\begin{array}{l}\text { 8. I take advantage of the first available opportunity to find out about new and } \\
\text { different singers and album. }\end{array}$ & 0.853 & 25.757 \\
\hline
\end{tabular}

Notes. All loadings are standardized; ${ }^{\#}$ SMFI=single most favourite idol; ${ }^{\mp}$ Reversed item. 
Table 3.

Descriptive Statistics

\begin{tabular}{|c|c|c|c|c|c|c|c|c|c|c|}
\hline & 1 & 2 & 3 & 4 & 5 & 6 & 7 & 8 & Alpha $^{a}$ & $\mathrm{CR}^{\mathrm{b}}$ \\
\hline 1. Parental Norms & $0.68^{c}$ & & & & & & & & 0.88 & 0.87 \\
\hline 2. Peer Norms & $0.44 *$ & 0.78 & & & & & & & 0.90 & 0.91 \\
\hline 3. Social Worship & $0.20 *$ & $0.33 *$ & 0.55 & & & & & & 0.90 & 0.88 \\
\hline 4. Personal Worship & $0.24 *$ & $0.35 *$ & $0.35 *$ & 0.67 & & & & & 0.89 & 0.89 \\
\hline 5. Purchase Intention & $0.23 *$ & $0.35 *$ & $0.29 *$ & $0.27 *$ & 0.67 & & & & 0.89 & 0.89 \\
\hline 6. Piracy Intention & 0.03 & 0.04 & 0.05 & $-0.22 *$ & $-0.16^{*}$ & 0.66 & & & 0.88 & 0.89 \\
\hline 7. Purchase Frequency & $0.10^{*}$ & $0.18^{*}$ & $0.13^{*}$ & $0.24 *$ & $0.35 *$ & $-0.19 *$ & ----- & & ----- & ----- \\
\hline 8. Piracy Frequency & 0.04 & 0.02 & 0.01 & -0.01 & $-0.10^{*}$ & $0.32 *$ & 0.01 & ----- & ----- & ----- \\
\hline Mean & 3.95 & 4.84 & 5.10 & 3.16 & 5.53 & 5.07 & 1.69 & 3.86 & & \\
\hline S. D. & 1.29 & 1.25 & 0.93 & 1.01 & 1.46 & 1.40 & 0.52 & 1.41 & & \\
\hline
\end{tabular}

Notes: $*=\mathrm{p}<.05 ; \mathrm{N}=723$

a Internal Consistency Reliability: Cronbach’s alpha coefficient.

b Composite Reliability (Fornell and Larcker 1981).

c Diagonal values in italics show average variance extracted (Fornell and Larcker 1981) for each construct. 
Table 4.

Structural Parameter Estimates and Goodness-of-Fit Indices for the Full Model

\begin{tabular}{clllll}
\hline Rows & Paths & Hypotheses & Estimate & S.E. & t-value \\
\hline 1 & Parental Norms $\rightarrow$ Social Worship & $\mathrm{H}_{1 \mathrm{a}}$ & 0.05 & 0.03 & 1.46 \\
2 & Parental Norms $\rightarrow$ Personal Worship & $\mathrm{H}_{1 \mathrm{~b}}$ & 0.08 & 0.04 & 1.85 \\
3 & Peer Norms $\rightarrow$ Social Worship & $\mathrm{H}_{2 \mathrm{a}}$ & 0.43 & 0.05 & $9.26^{*}$ \\
4 & Peer Norms $\rightarrow$ Personal Worship & $\mathrm{H}_{2 \mathrm{~b}}$ & 0.33 & 0.06 & $7.29^{*}$ \\
5 & Social Worship $\rightarrow$ Purchase Intention & $\mathrm{H}_{3 \mathrm{a}}$ & 0.46 & 0.05 & $10.69^{*}$ \\
6 & Social Worship $\rightarrow$ Piracy Intention & $\mathrm{H}_{3 \mathrm{~b}}$ & 0.12 & 0.04 & $3.03^{*}$ \\
7 & Personal Worship $\rightarrow$ Purchase Intention & $\mathrm{H}_{4 \mathrm{a}}$ & 0.10 & 0.04 & $2.49^{*}$ \\
8 & Personal Worship $\rightarrow$ Piracy Intention & $\mathrm{H}_{4 \mathrm{~b}}$ & -0.32 & 0.04 & $-7.44^{*}$ \\
9 & Purchase Intention $\rightarrow$ Purchase Frequency & $\mathrm{H}_{5 \mathrm{a}}$ & 0.37 & 0.03 & $9.53^{*}$ \\
10 & Piracy Intention $\rightarrow$ Piracy Frequency & $\mathrm{H}_{5 \mathrm{~b}}$ & 0.33 & 0.03 & $8.60^{*}$ \\
Control variable & & & & \\
11 & Novelty Seeking $\rightarrow$ Purchase Intention & & 0.02 & 0.05 & 0.52 \\
12 & Novelty Seeking $\rightarrow$ Piracy Intention & & 0.31 & 0.05 & $5.08^{*}$ \\
\hline \multicolumn{7}{c}{ p-value $=0.000$} & RMSEA d.f.) $=896.390 \quad$ Standardized RMR $=0.083$ & GFI=0.918 & & AGFI=0.903 \\
\hline
\end{tabular}

Notes: All estimates are standardized. ${ }^{*}=$ significant at the $\mathrm{p}<0.05$ level. 
Table 5.

Summary Results of Mediating Effects.

\begin{tabular}{llcl}
\hline Items & Relationships & Estimates Mediation $^{\#}$ \\
\hline
\end{tabular}

1. Mediating role of social worship between parental norms $\rightarrow$ purchase intention

Norms $\rightarrow$ purchase $.28^{*}$

Norms $\rightarrow$ worship $\quad .30^{*} \quad$ Sobel Z

Worship $\rightarrow$ purchase $\quad .51^{*}=5.90^{*}$

Norms $\rightarrow$ purchase (worship is included) $.14^{*}$

2. Mediating role of social worship between peer norms $\rightarrow$ purchase intention

$\begin{array}{lll}\text { Norms } \rightarrow \text { purchase } & .39^{*} & \text { Partial } \\ \text { Norms } \rightarrow \text { worship } & .47^{*} & \text { Sobel Z } \\ \text { Worship } \rightarrow \text { purchase } & .51^{*} & =7.01^{*} \\ \text { Norms } \rightarrow \text { purchase (worship is included) } & .19^{*} & \end{array}$

3. Mediating role of personal worship between parental norms $\rightarrow$ purchase intention

Norms $\rightarrow$ purchase $\quad .28^{*}$ Partial

Norms $\rightarrow$ worship $\quad .30^{*} \quad$ Sobel Z

Worship $\rightarrow$ purchase $\quad .34^{*}=4.37^{*}$

Norms $\rightarrow$ purchase (worship is included) $.21^{*}$

4. Mediating role of personal worship between peer norms $\rightarrow$ purchase intention
Norms $\rightarrow$ purchase
$.39^{*} \quad$ Partial
Norms $\rightarrow$ worship
$.40^{*} \quad$ Sobel Z
Worship $\rightarrow$ purchase
$.34^{*}=3.61^{*}$
Norms $\rightarrow$ purchase (worship is included)
$.32^{*}$

5. Mediating role of social worship between parental norms $\rightarrow$ piracy intention

$\begin{array}{lll}\text { Norms } \rightarrow \text { piracy } & .04 & \text { No } \\ \text { Norms } \rightarrow \text { worship } & .30^{*} & \text { Sobel Z } \\ \text { Worship } \rightarrow \text { piracy } & .01 & =0.40 \\ \text { Norms } \rightarrow \text { piracy (worship is included) } & .04 & \end{array}$

6. Mediating role of social worship between peer norms $\rightarrow$ piracy intention

$\begin{array}{lll}\text { Norms } \rightarrow \text { piracy } & .04 & \text { No } \\ \text { Norms } \rightarrow \text { worship } & .47^{*} & \text { Sobel Z } \\ \text { Worship } \rightarrow \text { piracy } & .01 & =0.32 \\ \text { Norms } \rightarrow \text { piracy (worship is included) } & .03 & \end{array}$

7. Mediating role of personal worship between parental norms $\rightarrow$ piracy intention
Norms $\rightarrow$ piracy
.04 Inconsistent
Norms $\rightarrow$ worship
.30* Sobel Z
Worship $\rightarrow$ piracy
$-.23^{*}=-4.30^{*}$
Norms $\rightarrow$ piracy (worship is included)
$.13^{*}$

8. Mediating role of personal worship between peer norms $\rightarrow$ piracy intention
Norms $\rightarrow$ piracy
.04 Inconsistent
Norms $\rightarrow$ worship
$.40^{*} \quad$ Sobel Z
Worship $\rightarrow$ piracy
$-.23^{*}=-5.34^{*}$
Norms $\rightarrow$ piracy (worship is included)
$.16^{*}$

Notes. All estimates are standardized; ${ }^{*}$ significant $\mathrm{p}<0.05$; ${ }^{*}$ Partial=partial mediation; no=no mediation; inconsistent=inconsistent mediation. 


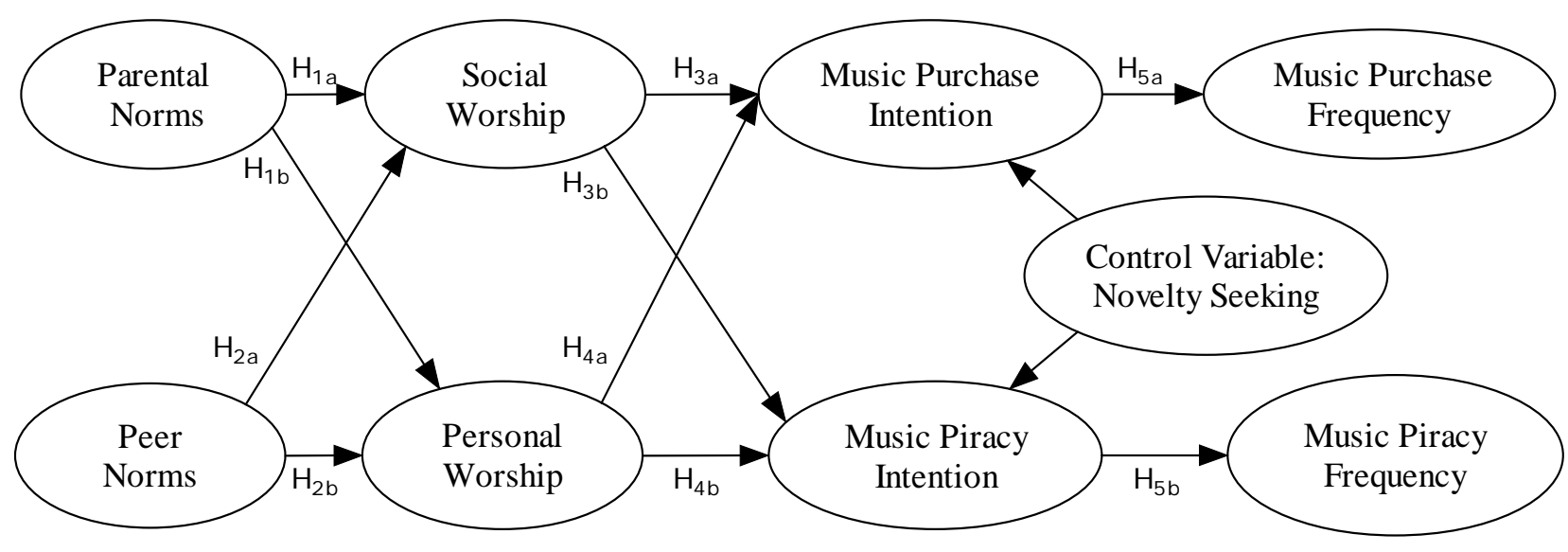

Figure 1.

Research Constructs and Hypotheses

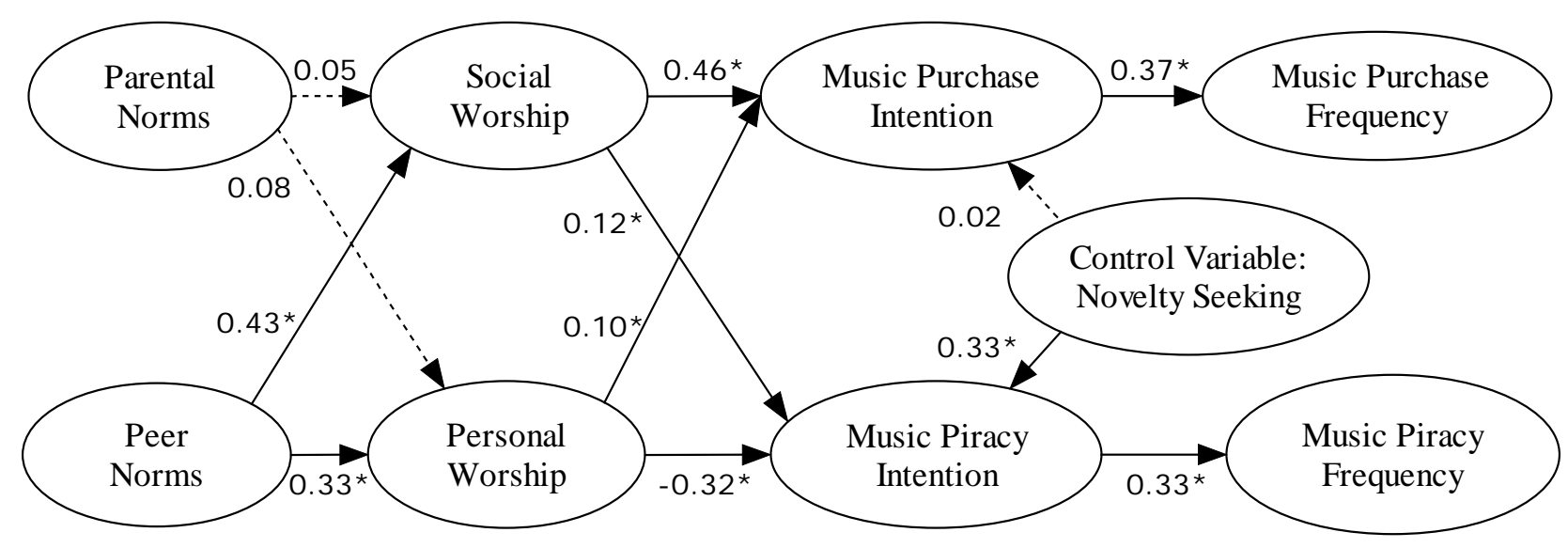

Note: All coefficients are standardised.

All solid line path coefficients are significant at $\mathrm{p}<0.05$. (The dotted line coefficient non-significant.)

${ }^{*} \mathrm{p}<.05$

Figure 2.

The Final Model 